\title{
Interrelations Between Prospective Teachers' Experiences Of Artistic Creativity And Diversity And Individuality As Professional Value
}

\author{
DOI 10.1515/sigtem-2016-0011
}

\begin{abstract}
The aim of the study is to investigate the possibilities of artistic creativity to foster the development of prospective teachers' professional values to enable an appreciation of the diversity and individuality. The central idea of the article is on the development of the student's values and its relation to a person's direct emotional experience of a particular value and reflective arrangement of its emotional trend and subjective sense. One of the modes of experience of artistic creativity - experience of the creative process - is analysed as a source for emotions, necessary for the initiation of the process of development of values. The analysis of qualitative and quantitative data reveals significant interconnections between prospective teachers' experience of creative process in art classes and their attitudes towards diversity and individuality as personally and professionally significant values. The results of the research enable us to provide suggestions about the content of visual art studies in teacher training curriculum, recommendable for facilitating the development of prospective teachers' professional competence.
\end{abstract}

Keywords: teacher's professional values, diversity as a value, artistic creativity, experience of creative process.

\section{Introduction}

The values are the things, ideas, persons or phenomena, which are of personal significance for the subject. According to this statement, a teacher's professional values have objective and subjective aspects. They are determined by objective reality and actual aims of education and, at the same time also by subjective evaluations, ideals and attitude of each individual teacher. Life-long professional development requires the teachers to be open-minded towards cultural diversity, fluidity, complexity and development of the individual potential of each student, which are the actual values of 21st century education, but the choices of pedagogical means in everyday pedagogical situation are led by teacher's personal set of values. The students' beliefs about the importance of actual principles of education and personal interest to realise them have the same importance as the quality of teachers' professional education, as well as their theoretical and practical knowledge (Patrick, Pintrich, 2001; Brundett, Silcock, 2002; Moore, 2004). The mission of teachers' education is to reveal diversity and individuality as personally significant values for prospective teachers to help them accept these challenging realities as a possibility for communication, cognition and development, not as threats or overpowering obstacles.

Artistic creativity is a strong means for communicating values, so it is supposed to be capable of revealing diversity and individuality as personally significant values for prospective teachers.

*Corresponding author: Ilze Briška: Riga Teacher Training and Educational Management Academy, E-mail: ilze.briska@rpiva.Iv 


\section{Aim of the Study}

The aim of the study is to investigate interrelations between the development of prospective teachers' notions of diversity and individuality as professional values artistic and their experiences of creativity in visual art classes.

\section{Materials and Methods}

Quantitative and qualitative methods are used for empirical research. The questionnaire (273 respondents) states the general interrelations in selection. The analysis of narrative interviews (10 respondents) helps to interpret the statistical data and fix the connections between particular approach to artistic creativity and the diversity and individuality as a personally meaningful value.

\section{Development of prospective teachers' professional values}

Analysis of the theories dealing with development of human motivation shows that the development of adult person's values is connected with the changes in the system of that person's inner motivational forces. Values development is initiated by emotions, and emotions are essential in all three stages of a process of values development:

- direct experience of a value,

- evaluation of the emotional trend of these experiences and

- analysis of the subjective sense of the experienced value.

All of them call for active participation and mental activity of the subject.

The result of values development is specific changes in person's values hierarchy and thereafter the person is motivated to realise the new value in meaningful action (Rogers, 1961; Dabrowski, 1967; Оллпорт, 1970, 2002; Леонтъев А., 1975; Karpova, 1994; Vidnere, 1999; Леонтъев Д., 1998; Schwarz, 2006).

It is appropriate to conclude that the experience - the totality of everything, what person undergoes in its wholeness of cognitive, affective and volition structures; past, present and future; person's individual qualities, its social and cultural contexts (Dewey 1979; Griffin, Holford, Jarvis, 2003) - is the key concept of adult person's values development. Therefore the development of student's values can be fostered with their involvement into primary emotional experience and a particular kind of reflection.

Two sources were analysed for generalising the opportunities to foster students' values development in the study process. One of them is constructivist didactic models. Experience and reflection are essential for them, and they are learning-oriented and interaction-oriented (Schön, 1987; Wood, 2001; Brundet, Silcock, 2002; Griffin, Holford, Jarvis, 2003; Tillıa, 2005; Hatton, Smit, 2006). Another source is adult education with its interest in authentic examination of the student's experience (Knowles, 1998; Tennant, 2006). These approaches do not deal with students' strongly primary emotional experience - the essential psychological condition for a person's values development. The artistic creativity is supposed to be the action, that is, which can provide such encounter.

\section{Specifics of artistic creativity}

The borders of visual art are determined by visual and material form, culturally significant content and aesthetic focus of evaluation. In the post-modern context, all these components can be extremely variable, according to Welsh: "the art predestinates itself for endless experiments of diversity" (Velšs, 2006, p.168). The form of an art varies from intimate impressionists painting to challenging contemporary performing activities, and the content from graphic design of bank notes to investigation of biotechnology for aesthetic aims. Aesthetic evaluation, which unites all this diversity, differentiates the art from other human activities because of its interest in unique, individual appearances of the outer world and human personality, 
sensuality, subjectivity and wholeness of artistic cognition, communication and creation (Spranger, 1928; Dewey, 1979; Kasīrers, 1997; Eisners, 1985; Gadamers, 2002; Д. Леонтъев, 1998; Freeland, 2001; Velšs, 2006). So, it is safe to say that artistic creativity indicates the realisation of diversity and individuality as values.

The research student is supposed be involved in artistic creativity, if she/he

- acts in the framework of visual art;

- creates independent, original product; and

- acts purposefully and consciously.

The specifics of artistic creativity can offer a specific kind of experience for a prospective teacher.

Leontjev announced that during each action its subject experiences (1) the object of the action, (2) the self as a subject of the action and (3) the action itself as subjects - objects interaction (Леонтъев А., 1975). This idea, related to the artistic action, helps to define and characterise three aspects of experience specific for artistic creativity:

1. The experience of art as an object of artistic action is related to aesthetic feelings. In the framework of this study, two aspects are taken into consideration: specific, reflective, distanced spiritual delight signifying the experience of beauty and aesthetic feelings, which encompass a vivid perception of wide range of strong emotions, caused by one's imagination and empathic co-experience of feelings of 'other'. The criterion of aesthetic experience is a person's turning to aesthetic phenomena of the outer world, and to the perception and differentiation of one's aesthetic reactions at the same time (Выготский, 1991; Spranger, 1928; Волкова, 1988; Gadamers, 2002; Kasīrers, 1944, 1997; Eisners, 1985; Velšs, 1996, 2005; Freeland, 2001).

2. In experience of the self as the subject of an action, the artist emotionally and in wholeness perceives himself as an author, a creator and a creative personality. As artistic creativity is 'manifesting' the subjective personality in the objective work of art, and this mode of experience can be called the experience of self-manifestation. Her or his attention is turned towards herself or himself (Маслоу, 1970, 2003; Cropley, 2000; Chiksentmihalyi, 2002).

3. A subject's interaction with the object during artistic creativity can be experienced as a creative process. It is supposed to be a complex array of positive emotions provoked by student's engagement into convergence with objects of his/her action, and concentration of his/her attention on the world outside him/her (Де Боно, 1997; Edwards, 1999; Cropley, 2000; Csikszentmihalyi, 2002).

Each experience possesses another emotion, which differentiates one experience from another (Dewey, 1974; Мазепа и др., 1980; Каган, 1997) (see Table 1).

Table 1. Emotional experience of artistic creativity

\begin{tabular}{|c|c|}
\hline Experience or artistic creativity & Emotions \\
\hline Experience of aesthetic feelings & $\begin{array}{l}\text { Aesthetic delight, elation, enjoyment, pleasure, satisfaction. } \\
\text { Different kinds of emotions: passion, animation, excitement, co-experience, empathy. }\end{array}$ \\
\hline Experience of self-manifestation & $\begin{array}{l}\text { Autonomy, self-enhancement, independence, freedom, power, courage, challenge. } \\
\text { Self-confidence, spontaneity, optimism, integrity, self-acceptance. }\end{array}$ \\
\hline Experience of creative process & $\begin{array}{l}\text { Interest, enthusiasm, surprise, exaltation vigilance, concentration, involvement. } \\
\text { Peacefulness, security, surrender, rejecting control, state of 'flow'. }\end{array}$ \\
\hline
\end{tabular}

If any of these aspects is absent, then his/her action is either not artistic, not creative or not purposeful. These three aspects of experience are used for the investigation of the impact of artistic creativity on the potential development of professional values in prospective teachers.

The working hypothesis was created on basis of theoretical analysis: prospective teacher appreciates diversity and individuality as professional values, if he has obtained the experience of aesthetic feelings, experience of self-manifestation and experience of creative process during his art studies.

The objectives of empirical research are to measure the level of diversity and individuality as prospective teachers' professional values, emotional trends of their experiences during art studies and to investigate interrelations between them. 
Quantitative and qualitative methods were used for empirical research. The questionnaire reveals general interrelations in selection, but the analysis of narrative interviews helps to interpret the statistical data. The programs SPSS and AQUAD6 were used for data processing.

The selection (273 respondents) was done using the randomization principle. Group includes full and part-time students of different teacher education programmes from three universities. Respondents differ by their age, work experience and quantity and quality of their artistic education. For interviews, 10 students with different attitude to diversity and individuality as values and different experience of art education were selected.

Prospective teachers' professional values and their experiences of artistic creativity were measured using a questionnaire. Students were asked to evaluate personal significance of 55 different statements about contradictory pedagogical phenomena (stable/mutable content of learning, instructional/constructive process of learning and individual/societal oriented pedagogical relationship) in Likert scale (from strongly disagree to strongly agree).

Factor analysis, used for data reduction (principal components and Varimax rotation), marked out 13 factors. One of them, the fourth factor, which united three variables - students appreciation to 'contradictions, surprises and adventures', 'individual, social and cultural differences' and 'personally significant choice and critical evaluation' - was classified as 'orientation towards diversity an individuality as values' (Briška, 2011).

Vivid expression of this factor (value of the NTILES of factor_4 is 4) was defined as advanced level of diversity and individuality as a value, but not a pronounced fourth factor (values of NTILES of factor_4 is 1 ) as a poor level of diversity and individuality as teacher's professional values.

For measurement of students' experience of artistic creativity, respondents were asked to assess each of its six aspects as positive (1), rather positive, than negative (2), negligible (3), rather negative than positive (4) or negative (5).

Kruskal-Wallis test was used for calculating statistically significant differences in selections with positive and negative experience of artistic creativity.

To be convinced about the validity of data interpretation, qualitative research was performed (Huber, 2004; Mayring, 2001). For qualitative investigation, the analysis of narrative interviews was chosen. In interviews, respondents turned freely to those periods and events in their biography of artistic education, which are subjectively more important for them. Interviews helped to ascertain prospective teachers' experiences - emotions and feelings, their subjective positions and non-predictable contexts and combinations as well as different types of relations between their experience of artistic creativity and their values.

Ten interviews, chosen for deeper analysis, describe different narratives of formal art education before studies and during studies. D and I have experienced full cycle (secondary and higher) of professional art education. Experience of J, L, V and K mostly included basic school and two credits at a pedagogical academy. R, M, A and C studied art pedagogy for three semesters.

Interviews were transcribed and processed in the program AQUAD6. In the beginning, they were looked through openly, at the same time attempting to keep free from expectations and conceptions, with a purpose to formulate what they are about and to accept that they are useful for the needs of the research (Huber, 2004). The texts were interpreted for hermeneutic understanding and functional equivalents (Rubene, 2004).

The system of codes was created in accordance with the hypothesis. It was structured into two categories: experience of artistic creativity $(\mathrm{P})$ and student's values $(\mathrm{V})$. Positive experience was related to positive emotions; negative to negative ones or lack of experience of artistic creativity and perception of its result - work of art. High or poor level of respondents' values was coded, when students expressed a particular attitude or evaluations related to diversity and individuality.

According to frequencies of codes, all cases were classified as representatives of high level (A, K, M, C, $\mathrm{R}$ ) and low level (D, I, V, J) of diversity and individuality as teacher's professional value. (Case L cannot be qualified as typical, because her values statements had the same number positive and negative perceptions.)

Content analysis shows similarities and differences between categories used by respondents with high and low level of values. 


\section{Results}

Kruskal-Wallis test reveals several statistically significant differences of diversity and individuality as prospective teachers' professional values in selections with positive and negative experience of artistic creativity (see Table 2).

Table 2. Kruskal-Wallis test: differences in the level of diversity and individuality as prospective teachers' professional values in selections with different experience of artistic creativity

\begin{tabular}{|c|c|c|c|c|c|c|c|c|c|c|}
\hline \multirow{5}{*}{ 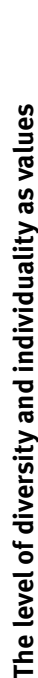 } & & \multicolumn{3}{|c|}{ Experience of aesthetic feelings } & \multicolumn{3}{|c|}{ Experience of self-efficacy } & \multicolumn{3}{|c|}{ Experience of creative process } \\
\hline & & 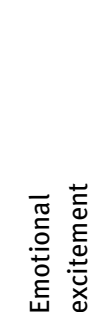 & 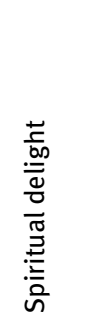 & $\begin{array}{l}\overline{\widetilde{\pi}} \\
\stackrel{0}{0}\end{array}$ & 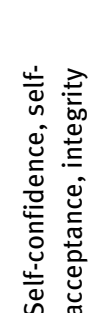 &  & $\begin{array}{l}\bar{\pi} \\
\stackrel{0}{0}\end{array}$ & 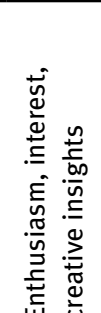 & 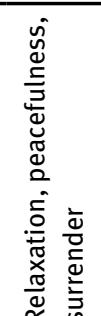 & $\begin{array}{l}\bar{\pi} \\
\stackrel{0}{0}\end{array}$ \\
\hline & Chi-Square & 20,427 & 11,228 & 18,575 & 3,821 & 7,953 & 3,061 & 16,698 & 11,023 & 14,094 \\
\hline & df & 4 & 4 & 3 & 4 & 4 & 3 & 4 & 4 & 3 \\
\hline & Asymp. Sig. &, 000 & 024 &, 000 & ,431 & ,093 & ,382 &, 002 & ,026 & ,003 \\
\hline
\end{tabular}

The intensity and emotional trend of experience of self-efficacy does not seem to have any relationship with diversity and individuality as professional values of prospective teachers. But concerning two other kinds of experiences - of aesthetic feelings and creative process - the interrelations are significant $(p<0.05)$.

The correlations between diversity and individuality as prospective teacher's professional values and their experience of creative process are analysed in the following.

The crosstab shows that for respondents with positive experience of creative process, the orientation towards diversity and individuality ( $4^{\text {th }}$ factor) is at an advanced or high level (37.8\% and $28.9 \%$ ) (see Table 3). The occurrence of advanced or high level is much smaller for respondents with negligible or rather negative experience (14.9\% and 20.4\%).

Table 3. Crosstab: Relations between 4th factor of students' values and their experience of creative process in art classes

\begin{tabular}{|c|c|c|c|c|c|c|}
\hline \multirow{2}{*}{$\begin{array}{l}\text { The level of } \\
\text { diversity and individuality } \\
\text { as values. }\end{array}$} & & \multicolumn{5}{|c|}{ Experience of creative process in art classes } \\
\hline & & Rather negative & Negligible & Rather positive & Positive & Total \\
\hline \multirow[t]{2}{*}{ Low } & \multirow{2}{*}{$\begin{array}{l}\text { Students } \\
\% \text { from column }\end{array}$} & 17 & 25 & 10 & 8 & 60 \\
\hline & & $31,5 \%$ & $28,7 \%$ & $19,2 \%$ & $17,8 \%$ & $25,2 \%$ \\
\hline \multirow[t]{2}{*}{ Mediocre } & \multirow{2}{*}{$\begin{array}{l}\text { Students } \\
\% \text { from column }\end{array}$} & 16 & 27 & 10 & 7 & 60 \\
\hline & & $29,6 \%$ & $31,0 \%$ & $19,2 \%$ & $15,6 \%$ & $25,2 \%$ \\
\hline \multirow[t]{2}{*}{ High } & \multirow{2}{*}{$\begin{array}{l}\text { Students } \\
\% \text { from column }\end{array}$} & 10 & 22 & 13 & 13 & 58 \\
\hline & & $18,5 \%$ & $25,3 \%$ & $25,0 \%$ & $28,9 \%$ & $24,4 \%$ \\
\hline \multirow[t]{4}{*}{ Advanced } & \multirow{2}{*}{$\begin{array}{l}\text { Students } \\
\% \text { from column }\end{array}$} & 11 & 13 & 19 & 17 & 60 \\
\hline & & $20,4 \%$ & $14,9 \%$ & $36,5 \%$ & $37,8 \%$ & $25,2 \%$ \\
\hline & \multirow{2}{*}{$\begin{array}{l}\text { Total } \\
\% \text { from column }\end{array}$} & 54 & 87 & 52 & 45 & 238 \\
\hline & & $100,0 \%$ & $100,0 \%$ & $100,0 \%$ & $100,0 \%$ & $100,0 \%$ \\
\hline
\end{tabular}


The inverse relationship, about the same proportion as $17 \%$ and $15 \%$ of students who had obtained positive experience of creative process, do appreciate diversity and individuality as values at a low or mediocre level, but in selections with rather negative and negligible experience, such attention is considerably bigger $-29.6 \%$ un $31.5 \%$.

As Kruskal-Wallis test confirms that difference between selections with positive and negative experience of creative process is significant ( $p=0.003$ ), with a little possibility of error, the null hypothesis can be rejected. The conclusion that experience of creative process has important interrelations with diversity and individuality as prospective teachers' professional values is valid. In Table 4, the expressions of all respondents of the interviews are structured.

Table 4. Categories and expressions used for description their experience of creative process

\begin{tabular}{|c|c|c|c|}
\hline Concept & $\begin{array}{l}\text { Cases with high level of diversity and } \\
\text { individuality as value }\end{array}$ & All cases & $\begin{array}{l}\text { Cases with low level of diversity } \\
\text { and individuality as value }\end{array}$ \\
\hline $\begin{array}{l}\text { Positive } \\
\text { experience }\end{array}$ & $\begin{array}{l}\text { Spontaneity (to do it spontaneously). } \\
\text { Contradictions, challenge (to see/ } \\
\text { think) in inverted manner). } \\
\text { Concentration } \\
\text { Feeling freedom (to acquire, to untie, } \\
\text { very free, feeling like in fly, to express } \\
\text { myself freely). } \\
\text { Openness (to feel, that everything } \\
\text { opens, the heart opens, not the } \\
\text { knowing, but senses). } \\
\text { Lifestyle (to live in the world of } \\
\text { myself). }\end{array}$ & $\begin{array}{l}\text { Enthusiasm, interest (to be engaged in } \\
\text { the process, to have an inspiration, to } \\
\text { spend plenty of time for it - till three } \\
\text { o'clock at night, never try to finish as } \\
\text { soon as possible). } \\
\text { s Discovery (to have never done before, } \\
\text { thought about..., to do it at first time in } \\
\text { my life). } \\
\text { Fluency (easy, without torment and } \\
\text { problems, simply). } \\
\text { Rejecting control (images came, idea } \\
\text { emerges, the hand began to draw } \\
\text { of itself, something took shape, the } \\
\text { drawings appeared). }\end{array}$ & $\begin{array}{l}\text { Desire, will (to draw, to be able). } \\
\text { Requirements (we had to mix the } \\
\text { pigments, to search). } \\
\text { Relaxation (slackening). } \\
\text { Automatism (to do it automatic) } \\
\text { External influence He (the teacher) } \\
\text { untied me. }\end{array}$ \\
\hline $\begin{array}{l}\text { Negative } \\
\text { experience }\end{array}$ & $\begin{array}{l}\text { Lack of freedom (it was not possible to } \\
\text { express myself, she obliged). } \\
\text { Lack of challenge (we did things, we } \\
\text { wanted, but there was nothing new). } \\
\text { Automatisms (to do automatic). } \\
\text { Reticence (everything closed, and I } \\
\text { did not want to do anything). }\end{array}$ & $\begin{array}{l}\text { oLack of enthusiasm (boredom, it seems } \\
\text { to me, that drawing lessons are there } \\
\text { too many, to have not anything to do } \\
\text { there). } \\
\text { Lack of fluency (it didn't come easy, } \\
\text { difficult, with torture, to try, to have to } \\
\text { force). }\end{array}$ & $\begin{array}{l}\text { sExpectations (to do wrong). } \\
\text { Fear. } \\
\text { Rational control (if you try to think } \\
\text { about it, the image disappears). }\end{array}$ \\
\hline
\end{tabular}

The common characteristics of positive and negative experience of creative process are expressed in three categories - enthusiasm and interest/lack of them, discovery/boredom and fluency/tortures - which are the general concepts of creative process. But more interesting are the differences in expressions; they help to understand what kind of artistic creativity is more helpful for students' values development.

The main differences we can see in respondents' attitudes to requirements (outer or inner) is to challenge, to freedom and to automatism.

Students with poor level of diversity and individuality as values expand understanding of the creative process towards any requirements, i.e. their orientation to the result of art work is stronger than concentration to the process. Students, who appreciate diversity and individuality highly mention spontaneity and openness - contradictory concepts to direct will or expectations, which supposes any before-known criteria for evaluation.

Another difference can be explained with Chikszentmihalyi's (2002) idea about "flow" as equilibrium of challenge and abilities. In their experiences, respondents with high level of diversity and individuality as values recognise exercises for imagination, associations, construction, the challenging modes of thinking, but respondents with low level of values mentioned relaxation as rest and slackening, without balance with active discovery. 
The concept of freedom is used only by respondents with high level of values (A, M, R). They understand freedom as opportunity for self-expression, rather than students with low level of diversity and individuality as values; freedom can be associated only with relaxation, not disturbing.

The conclusion can be drawn that prospective teachers' experiences of artistic creativity during art classes have considerable interrelations with diversity and individuality as their professional values. This finding explains the Kruskal-Wallis test results that the differences between selections with positive and negative experience of enthusiasm, interest and creative insights are more significant than differences between students with different experience of relaxation, peacefulness, surrender ( $p=0.002$ and $p=0.026$ ). Such results let to reason that for realisation diversity and individuality as values, enthusiasm and challenge are more essential as experience of relaxation and comfort.

\section{Conclusions}

The prospective teachers' experience of creative process in art classes has very significant correlations with diversity and individuality as their professional values. The more positive is students' experience, high is the level of diversity and individuality as their values.

The content of the experience of creative process is of great importance. Students' enthusiasm, interest, delight and joy, reliance and involvement into flow during the creative process are not sufficient experiences for positive development of prospective teachers' professional values. The feeling and awareness of freedom, creative insights and meeting the challenge are more essential here.

The evaluation of students' direct experience of artistic creativity is in a great importance too. Sensitivity towards learner's feelings and courage are more effective criteria as orientation towards social stereotypes, professionalism and external demands.

The research does not validate the artistic creativity as a crucial factor of students' values development, but it reveals the pedagogical opportunities of artistic creativity to create objective situation for high appreciation of diversity and individuality as students' values.

For promoting the development of student teachers' professional values in art classes it makes sense

- to offer the opportunity to meet and express different emotions and feelings (not only delight and enthusiasm) in their creative works;

- to arrange the content of artistic creativity as challenging exercises of intellectual capacities (not only free expression oriented works);

- to stimulate the concentration on creative process (not only to professional result of artwork);

- to provide students' reflection on individual emotional reactions and recognition of one's social stereotypes;

- to highly appreciate creativity, originality, expressivity and subjectivity in students art works.

\section{References}

Briška I. (2011). Topošo skolotāju profesionālo vērtību attīstība mākslinieciski radošā darbībā. Promocijas darbs, LU Akadēmiskais apgāds, 255 lpp.

Brundrett Mark, Silcock Peter (2002). Achieving Competence, Success and Excellence in Teaching. Routledge Falmer, 184 lpp. Csikszentmihalyi, M (2002), Flow: The Classic Work on How to Achieve Happiness, Rider, London 314 p. Cropley (2000). Defining and Measuring Creativity: Are Creativity Tests Worth Using. Roeper Review, Vol. 23, Dabrowski, K. (1967). Personality shaping through positive disintegration. Boston: Little, Brown, 270.p. Dewey, John (1974) Experience and education. Collier Books New York, Collier Macmillan, London, 91 p. Dewey, John (1979) Art as Experience. A Paragon Book, New York, 355 p.

Edwards, Betty (1999). Drawing on the right side of the brain. Penguin Putnam Inc. New York, $291 \mathrm{p}$. Eisner, Eliot, W, (1985), The art of educational evaluation. The Falmer Press, London\&Philadelphia, 275 p. Freeland, Cynthia (2001) Art theory, Oxford University press, Oxford, $158 \mathrm{p}$.

Gadamers Hanss Georgs (2002), Skaistā aktualitāte: māksla kā spēle, simbols un svētki. Zvaigzne ABC, Rīga, 128 lpp. Hatton, Neville, Smith, David (2006) Reflection in teacher education: towards dfinition and implementation. The University of Sydney 
http://alex.edfac.usyd.edu.au/LocalResource/Study1/hattonart.html Huber, Gunter, L. (2004). AQUAD Six. Workshop. LU, Riga, 44 p.

Kasīrers, Ernsts (1997) Apcerējums par cilvēku. Intelekts, Rīga, 222 lpp.

Knowles, Malcolm (1998). The adult learner. Gulf Publishing Company, 310 p.

Kron Friedrich W. (2004) Grundwissen Didaktik, Ernst Reinhard Verlag, Minhen, Basel, $266 \mathrm{~s}$.

Griffin, Colin, Holford John, Jarvis Peter (2003). The Theory \& Practice of Learning. Kogan Page. London, $198 \mathrm{p}$.

Karpova Ā. (1994). Personība un individuālais stils. Latvijas Universitāte, Rīga. 291 lpp.

Mayring, Philipp (2001). Combination and Integration of Qualitative and Quantitative Analysis, Forum: Qualitative social research, http://www.qualitative-research.net.fgs.

Moore, Alex (2004). The good teacher. Routledge Falmer, London, NY, 191 p.

Patrick Helen, Pintrich Paul R. (2001). Conceptual Change in Teachers' Intuitive Conceptions of Learning, Motivation, and

Instruction.//Understanding and Teaching the Intuitive Mind: Student and Teacher Learning. Sternberg R.J., Torff B., eds.

Lawrence Erlbaum Associates, Mahwah, NJ, 117 - 141 p.

Rogers C.Carl (1961) On Becoming Person. Houghton Mifflin Company, Boston, 420 lpp.

Rogers C.Carl (1967) Modern approach to Values: maturity. The Macmillan company, New York, 40 - 54 lpp.

Rubene Zanda (2004). Kritiskā domāšana studiju procesā, LU Akadēmiskais apgāds, Rīga, 247 lpp.

Schön, D (1987) Educating the Reflective Practitioner, Jossey-Bass, London, 355 p.

Schwarz, Shalom H. (2006) Basic Human Values: Theory, Methods, and Applications. The Hebrew University of Jerusalem. http://www.fmag.unict.it/Allegati/convegno\%207-8-10-05/Schwartzpaper.pdf

Spranger, Eduard (1928) Types of men: the Psychology and ethics of personality. M.Niemeyer. Halle, $404 \mathrm{p}$.

Tennant Mark (2006). Psychology and adult learning, Routledge, London, NY, 342 p.

Tillı I. (2005). Sociālkultūras mācīšanās organizācijas sistēma. Raka, Rīga, 295 lpp.

Velšs, Volfgangs (2006). Estētikas robežceḷi. Zvaigzne ABC, Rīga, 340 lpp.

Vidnere, Māra (1999). Pārdzīvojuma pieredzes psiholog̣ija, Raka, Rīga, 73 lpp

Wood, Diana (2001). Teacher as Citizen: Professional Development and Democratic Responsibility Transforming Teacher

Education: Lessons in Professional Development (2001). Ed. By E. K. Demulder, P. C. Lepage, H. T. Sockett, D. R. Wood.

Bergin and Garvey. Westport, $257 \mathrm{p}$.

Боно Э. Де (1997) Латеральное мышление. Питер Санкт-Петербург, 316 с.

Борев, Юрий (1988). Эстетика. Политиздат, Москва, 495 с.

Выготский Лев Семенович (1991). Воображение и творчество в детском возрасте. Просвещение. Москва, 90 стр.

Выготский Лев Семенович (2000). Психология искусства. Санкт-Петербург, Азбука, 410 с.

Волкова Е.В. (1988). Произведение искусства в мире художественной культуры. Искусство, Москва 239 с.

Каган Моисей Самоилович (1997). Эстетика как философская наука. Петрополис, Санкт-Петербург, 544 с.

Мазепа В.И., Иванов В.И., Малахов В.А., Лысый И.Я., Яранцва Н.Я. шудрая Е. П., Михалев В. П., Федорук В.С. (1980),

Художественная деятельность. Проблема субъекта и объектвной и дететрминации. Наукова думка, Киев, 293 с.

Леонтъев А.Н. (1975) Деятельность. Сознание. Личность. Москва, Издательство политической литературы

Леонтъев, Д. (1998) Введение в психологию искусства. Московский университет, Москва 110 с.

Маслоу Абрахам. (2003) Мотивация и личнось. Питер, Санкт-Петербург, $351 \mathrm{lpp}$.

Оллпорт, Гордон (2002). Становление личности, Смысл, Москва, 462 с.

Столович, Леонид (1999). Философия. Эстетика. Смех. С.Петербург - Тарту. 